\title{
Survey, Excavation, and Geophysics at Songjiaheba-A Small Bronze Age Site in the Chengdu Plain
}

\author{
$\boldsymbol{\Delta} \cdot \boldsymbol{\Delta} \cdot \boldsymbol{\Delta}$ \\ ROWAN FLAD, TIMOTHY J. HORSLEY, JADE D’ALPOIM GUEDES, \\ HE KUNYU, GWEN BENNETT, POCHAN CHEN, LI SHUICHENG, \\ AND JIANG ZHANGHUA
}

\section{INTRODUCTION}

The Chengdu 成都 Plain, in the northwest corner of the Sichuan 四川 Basin (Fig. 1 ), was the setting for the emergence of a complex civilization in the second millennium B.C. This civilization is most notably associated with the site of Sanxingdui 三星 堆, in Guanghan 廣漢, where two sacrificial pits discovered in 1986 revealed a rich and unexpected collection of jade objects, ceramics, elephant tusks, and elaborate bronze and gold objects (Bagley 2001; Flad 2012; Sichuan 1999). The discovery of the Sanxingdui pits was followed by research at other sites in the Chengdu Plain, including several loci in the city of Chengdu that post-date Sanxingdui, such as an elite residential location called Shi'erqiao 十二橋 (Jiang 1998; Sichuan et al. 1987), a zone of ritual deposits, cemeteries, and settlement areas named Jinsha 金沙 (Chengdu and Beijing 2002; Chengdu Institute 2006; Zhu et al. 2003), and Shangyejie 商業街, a Late Bronze Age elite burial site with large log coffins filled with lacquers and other elite objects (Chengdu 2002). Based on the excavations of these sites, we now know that bronze-producing communities that commanded multi-community networks of resource acquisition existed in the Chengdu Plain starting at least as early as the middle of the second millennium B.C. (Flad and Chen 2013).

Elsewhere in the Chengdu Plain, research in the last two decades has also located nine walled sites that pre-date Sanxingdui and that collectively comprise most

Rowan Flad is a professor in the Department of Anthropology at Harvard University, Cambridge, Massachusetts, U.S.A.; Timothy J. Horsley is Adjunct Assistant Professor in the Department of Anthropology, Northern Illinois University, De Kalb, IL, U.S.A.; Jade D'Alpoim Guedes is an Assistant Professor in the Department of Anthropology at Washington State University, Pullman, Washington, U.S.A.; He Kunyu is at the Chengdu City Institute of Archaeology in Chengdu, P.R. China; Gwen Bennett is a professor in the Departments of Anthropology and East Asian Languages and Civilizations, McGill University, Montreal, Canada; Pochan Chen is Assistant Professor in the Department of Anthropology, National Taiwan University, Taipei, Taiwan; Li Shuicheng is Professor in the Department of Archaeology and Museology, Peking University, Beijing, P.R. China; Jiang Zhanghua is Vice Director at the Chengdu City Institute of Archaeology, Chengdu, P.R. China. 


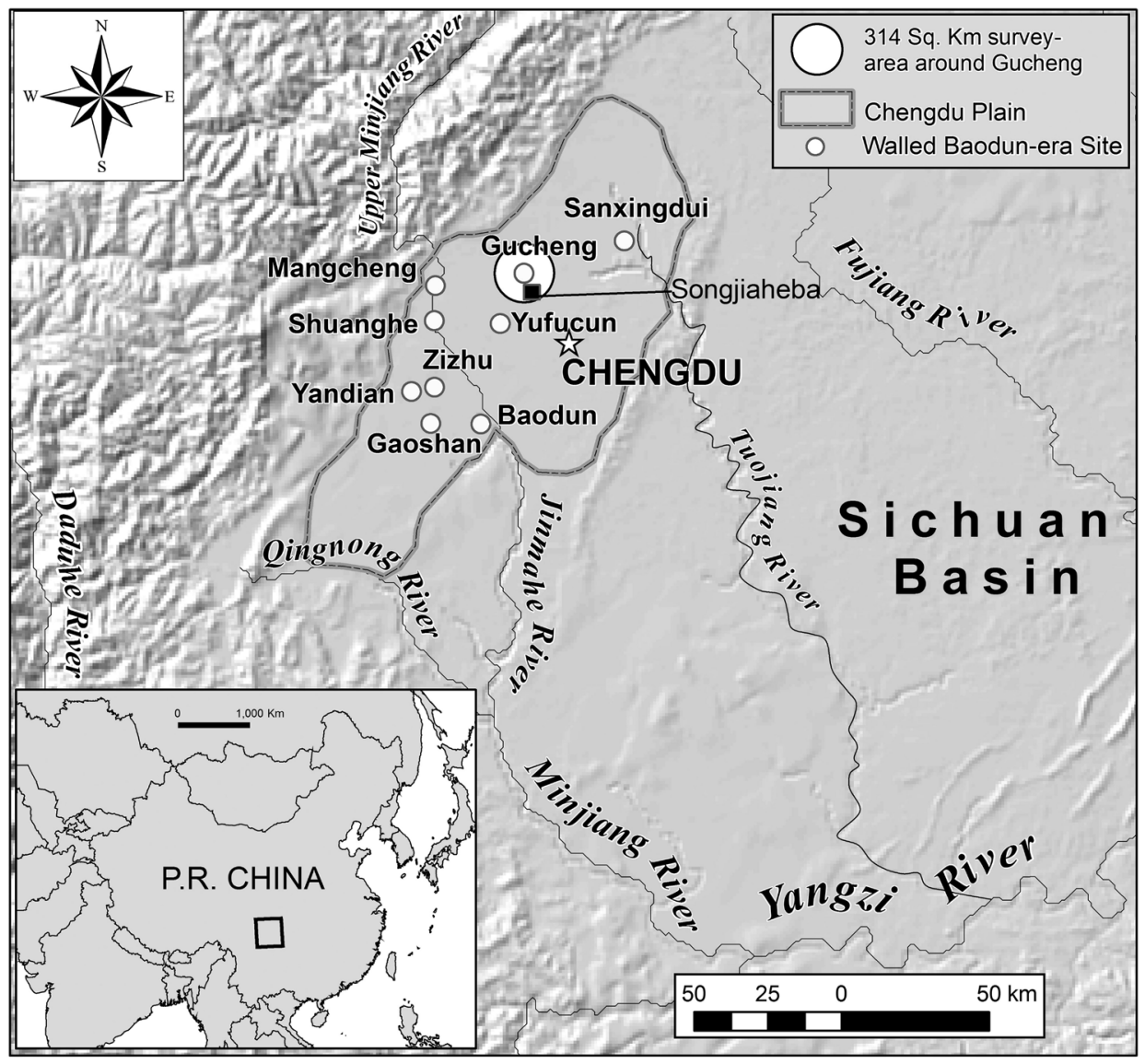

Fig. 1. Map of the Chengdu Plain with the locations of Sanxingdui (in Guanghan), Gucheng and Songjiaheba (in Pi Xian), and other Baodun era walled sites. The $314 \mathrm{~km}^{2}$ survey area around Gucheng is also shown.

evidence for the Late Neolithic Baodun 寶墩 culture (Chengdu et al. 2000; Wang 2003). The Baodun culture is characterized by certain fine-ware ceramics, groundstone tools, and wattle-and-daub architectural features that have been discovered at these walled sites. There is no evidence that these walled sites were integrated into a single large regional polity, but large building foundations at several of them suggest that they may have acted as central places for more localized multisite corporate groups, perhaps as loci of ritual activity, elite compounds, or refugia for residents at scattered house compounds or small hamlets. The walls at the sites required communal labor investment for their construction, thereby supporting the notion that they were occupied and maintained by fairly sizable populations. The walls also fit into a pattern of increasing social complexity seen across China during the late Neolithic (Demattè 1999; Liu 1996; Ren 1998; Underhill 1994; Underhill et al. 1998, 2002; Xu 2000; Yan 1999; Yang 2004). The preliminary work done at these Neolithic walled sites, together with the research on Sanxingdui, Jinsha, Shangyejie, and other loci around Chengdu, has produced a basic archaeological chronology for the region (Table 1). 
Table i. Chronological Sequence for the Region

\begin{tabular}{|l|c|}
\hline CULTURE & APPROXIMATE DATES B.C. \\
\hline Baodun & $2700-1700$ \\
\hline Sanxingdui & $1700-1150$ \\
\hline Shi'erqiao (Jinsha) & $1200-800$ \\
\hline Xinyicun & $800-500$ \\
\hline Qingyanggong (Shangyejie) & $500-300$ \\
\hline
\end{tabular}

At present, our basic understanding of the social developments in this region is based mainly on the investigation of these large, politically central sites. This research has allowed researchers to posit a transition of political power, and possibly population migration, from Sanxingdui to Jinsha and other loci in Chengdu during the middle part of the Bronze Age. This transition may have been violent, as we have iconographic evidence for war captives in the form of kneeling stone human figurines with hands bound behind their backs at both sites (Chengdu Wenwu 2006). Furthermore, non-functional weapons made of jade from both of these sites reflect the symbolic importance of artifacts of war in the associated society. ${ }^{1}$ It is estimated that the Sanxingdui-Shi'erqiao transition took place sometime around $1200-1150$ B.C. (Xu 2003).

Research to date has not, however, provided a systematic understanding of settlement patterns in the region, nor has much attention been paid to small sites, which were distributed across the plain and probably housed a considerable portion of the population. Small settlements are poorly known from all parts of China throughout the Bronze Age because archaeologists have tended to focus on locations that are perceived to have been political centers. In the Central Plains of North China, for example, attention has been focused almost entirely on cemeteries or large, walled settlements, many of which are often identified by researchers as possible former capitals of the dynastic houses that ruled the region according to traditional histories. Recent survey work and increased attention to smaller settlements has begun to mitigate this bias. ${ }^{2}$ In the Sichuan basin, research on small sites has occurred occasionally in the Three Gorges and in areas around Chengdu where, respectively, a large dam project and urban development have created ad hoc opportunities for small settlements to be investigated (discussed in Flad and Chen 2013), but understanding of such sites has remained underdeveloped because of lack of systematic survey work and a predisposition to concentrate attention on larger sites with walls or relatively abundant, stratified deposits. A basic understanding of smaller settlements is vital, however, if we wish to begin to examine the broader network of communities that sustained the emergence of complexity. This is true in Sichuan as well, where very little attention has been paid to small settlements and their distribution. How widely spread and densely packed were settlements across the plain during various periods in the cultural chronology in this region? How diverse were these sites and what was their basic composition?

From 2005 to 2011, a large-scale survey project was conducted by archaeologists from the Chengdu City Institute of Archaeology, Peking University, Harvard 
University, Washington University in St. Louis, McGill University, and National Taiwan University to answer some of these questions (Chengdu 2010). This project, the Chengdu Plain Archaeological Survey (CPAS), is part of a trend in Chinese archaeology to develop an understanding of settlement patterns through systematic regional survey. ${ }^{3}$ Many of the surveys cited here have added crucial new data to our understanding of how early complex polities operated at a regional scale by outlining the spatial relationships among contemporary sites throughout several phases of prehistory. Similarly, CPAS aims to produce data that are representative of settlement patterns during the Baodun, Sanxingdui, Shi'erqiao, and later periods, and discuss the relationships among settlements during these different chronological phases.

As explained extensively elsewhere (Chengdu 2010), the survey procedures adopted by the CPAS project have been tailored to the particular features of the Chengdu Plain landscape, which is dominated by rice paddies, low degrees of surface visibility, and dispersed house compounds. Over the course of five seasons of fieldwork (designated 05, 06, 08, 09 and 10), we systematically examined approximately 347.5 square $\mathrm{km}$ using teams of archaeologists walking at approximately $50 \mathrm{~m}$ intervals throughout a highly fragmented landscape of agricultural fields and house compounds. The survey team collected all ceramics that were thought to belong to the Han period or earlier and marked these "find-spots" with GPS coordinates. Artifacts discovered in terrace walls, stream banks, or other exposed profiles were similarly collected, and finds within 20-30 m were collected together. In cases where Han period decorated bricks or other identifiable architectural elements were identified, these were photographed and marked, but not always collected. Find-spots for surface collections are marked on Figure 2.

Due to poor ground visibility in many fields and the fragmented nature of the landscape being surveyed, we combined traditional field-walking survey techniques with systematic augering along transects to identify site densities and general patterns of settlement. Our procedure involved the coring of four auger holes at "primary points" located at approximately $200 \mathrm{~m}$ intervals along transects that cross the survey area. A total of 1,988 primary points were investigated over the course of the project. In those places where one or more of these primary holes recovered Han or earlier remains, additional "secondary points" were cored along transects extending in the cardinal directions from the primary point. Secondary points were first cored $10 \mathrm{~m}$ from the original point, and when additional archaeological materials were discovered, the coring continued at successive $20 \mathrm{~m}$ intervals along the four transects. In Figure 2, those locations where "secondary auger points" are marked near primary auger points are places where subsurface remains indicated concentrated loci of archaeological remains. These "activity areas" are the focus of the various research projects of the CPAS project.

Compared to previous work in the region, the CPAS project has been much more extensive. Most previous work has opportunistically focused on sites that were under threat from construction projects, or surveys of areas to be affected by road or railroad routes. Little effort has previously been focused on ensuring the representativeness of the data being collected whereas CPAS is aimed at creating a systematically collected picture of the area. The survey has focused primarily on a roughly circular area with a $10 \mathrm{~km}$ radius surrounding the walled Baodun-culture site of Gucheng 古城 in Pi 䣃 County (see Figures 1 and 2), as well as a secondary zone around the site of Yufucun 魚鳥村 in Wenjiang 溫江 County, and has been able to identify many small sites in 


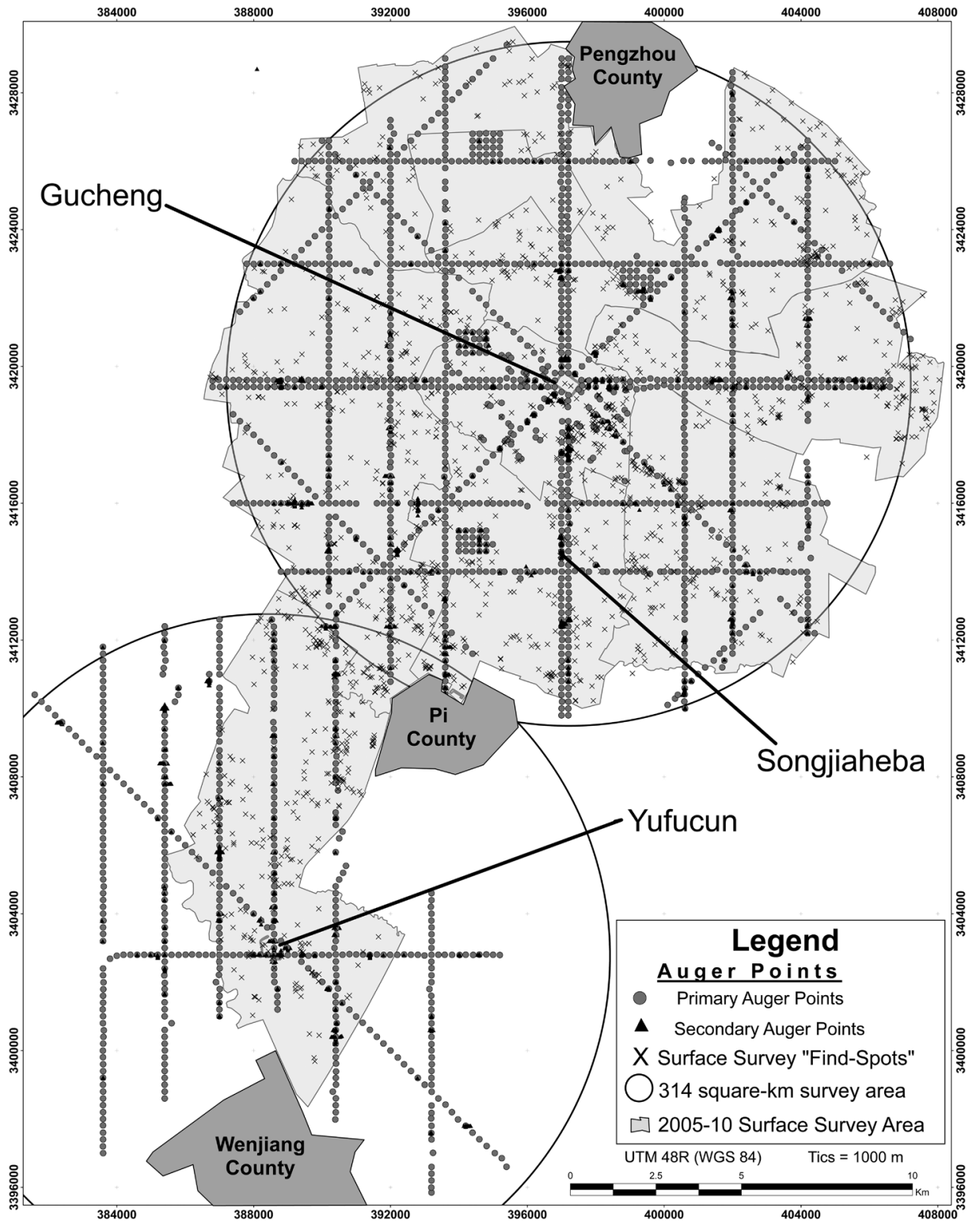

Fig. 2. Locations of surface survey "find-spots" and "primary" and "secondary" auger holes from the subsurface component of the CPAS project. The sites of Gucheng, Yufucun, and Songjiaheba are also indicated.

this region. The general results of the survey project are beyond the scope of this article, but will be the subject of a project report currently in preparation.

In addition to establishing a new perspective on spatial patterns of settlements across the Chengdu Plain, CPAS has focused on evaluating the nature of small-scale settlement areas. As the CPAS survey area sites have been discovered, the project team has evaluated their integrity, size, and composition through augering, as well as 
geophysics and small-scale excavations at some locations. Archaeological geophysics has not been used extensively or effectively in Chinese archaeology. This project marks one of the first attempts to employ high-resolution geophysics for any archaeological purpose in China. As such, it remains a procedure that requires extensive groundtruthing, but the CPAS project has shown that it can be an effective approach for a variety of purposes in Chinese archaeology, including the evaluation of small-scale settlements.

Among the first of the CPAS sites to receive extensive attention was Songjiaheba 宋家河壩, which was threatened by local villagers extracting natural sand and gravel deposits from the site. Research at Songjiaheba demonstrated that it was a small residential area during the second half of the second millennium B.C., roughly contemporary with the transition between the Sanxingdui and Shi'erqiao cultures. The research at Songjiaheba represents the first study of a small settlement from this period. It was also the first use of high-resolution geophysics in combination with survey and excavation data to understand a site of this nature in China.

\section{SITE DISCOVERY}

The site of Songiiaheba (centered on 0396996E 3414501N UTM Zone 48R, see Figure 2) is located in Sandaoyan 三道堰 Township in Pi County. It was discovered in 2006 by both surface survey and augering during the second CPAS season. Surface survey identified several find-spots in close proximity to one another at Songjiaheba,

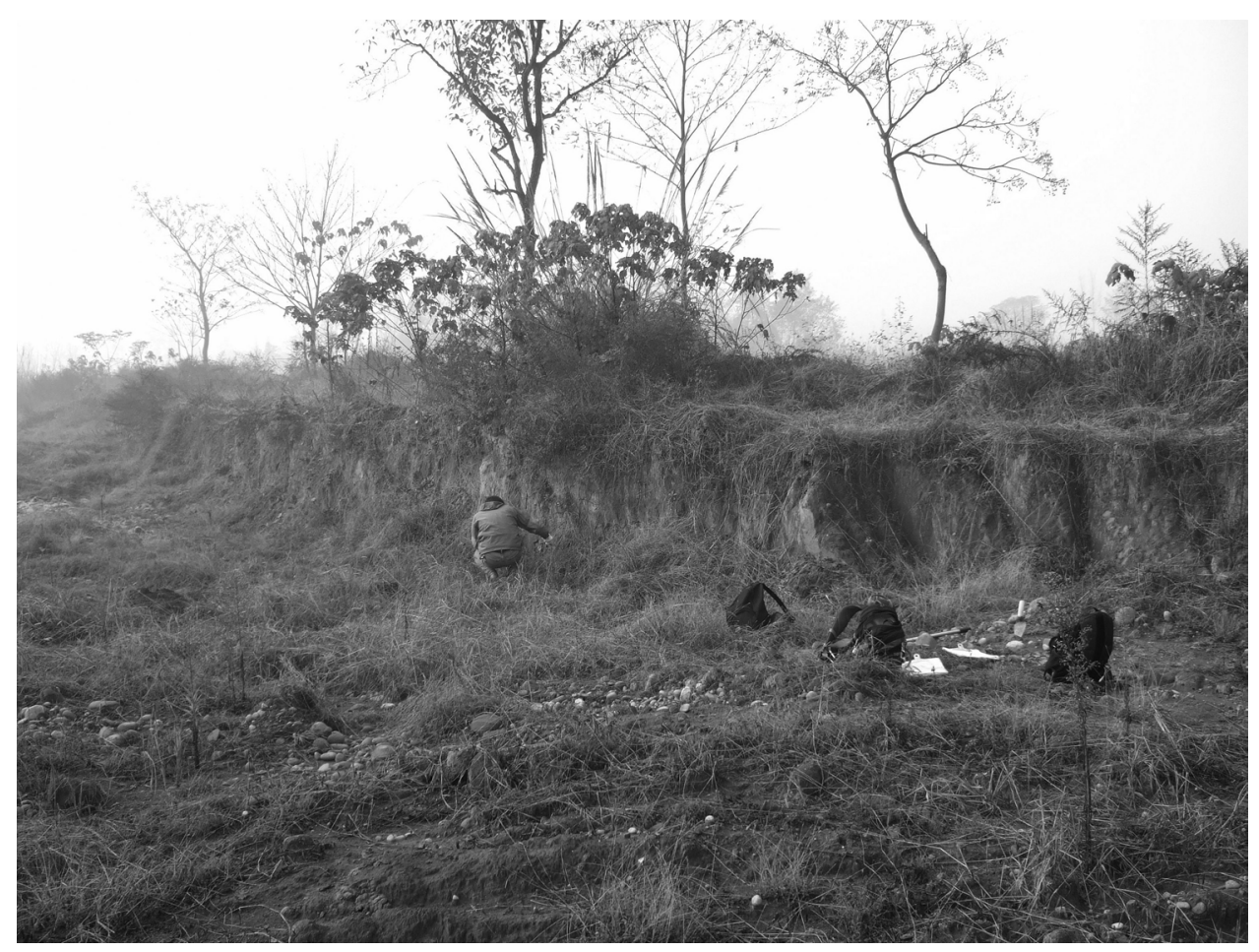

Fig. 3. Surface survey team discovering Songjiaheba in 2006. 
mostly in profiles left behind by the sand and gravel extraction (Fig. 3). Parts of the site had been removed by sand quarrying. There were, in fact, three tiers present. On the eastern part of the site, the original ground surface was preserved. In the central area, where the best preserved cultural levels seem to be located, approximately $0.6 \mathrm{~m}$. of the topsoil had been removed to create a flat area. The western portion of the site was the location of the sand-borrow pit (Fig. 3 and Plate 1).

Subsequently, the auger survey transect crossed through the same location and two consecutive primary points were drilled within anthropogenic deposits (Plate 1 and Fig. 4). These primary points showed that anthropogenic soils were present on the terrace to the east of the sand-borrow pit. Subsequently, secondary points augered along transects in cardinal directions extending outward from the primary points allowed us to estimate that the preserved portion of the site extended approximately $220 \mathrm{~m}$ from north to south, and reached east of the sand-borrow pit approximately $100 \mathrm{~m}$ (see Plate 1 for locations of surface survey finds, primary points and secondary points at the site, along with the relative abundance of datable archaeological material from the various locations). Whereas the ceramics recovered from these auger holes were similar to those collected during the surface survey, the auger holes were more effective at helping delineate the extent of the site. Surface finds, while ubiquitous on one side of the borrow pit, did not extend to the east where intact subsurface remains were found. The materials date primarily to the Bronze Age, a period from which few small-scale settlement sites have been identified or investigated in the Chengdu Plain.

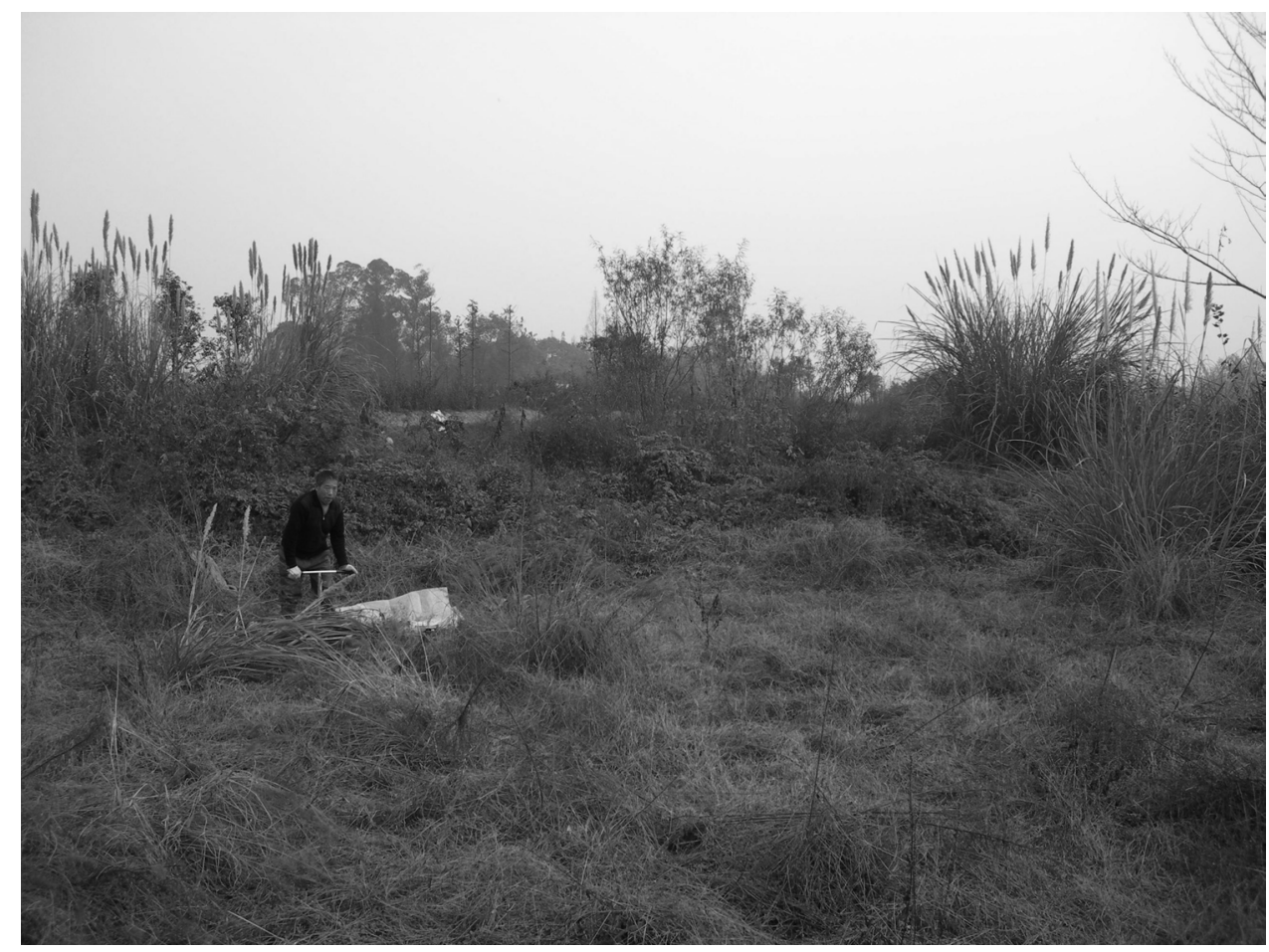

Fig. 4. Auger survey at Songjiaheba in 2006. 
Table 2. Radiocarbon Dates from Songjiaheba

\begin{tabular}{|c|c|c|c|c|c|}
\hline FCN & LAB \# & $\begin{array}{c}\text { SAMPle } \\
\text { TYPE }\end{array}$ & $\begin{array}{c}{ }^{14} \mathrm{C} \text { DATE } \\
(5568 \text { HALF-LIFE })\end{array}$ & $\begin{array}{c}\text { B.C. DATE } \\
(\mathrm{I} \text { SIG })\end{array}$ & $\begin{array}{c}\text { B.C. DATE } \\
(2 \text { SIG })\end{array}$ \\
\hline 2261 & BA08691 & Charcoal & $2925 \pm 35$ & $1210-1050$ & $1260-1010$ \\
\hline 2262 & BA08692 & Charcoal & $3155 \pm 35$ & $1495-1475 / 1460-1406$ & $1510-1370$ \\
\hline
\end{tabular}

The auger testing at the site suggested that there were two cultural strata present. This was confirmed in the profile exposed by the sand-borrow pit. Samples of carbonized materials were collected during the site assessment from the edge of the borrow pit at location 06PXC0005. One (FCN 2261) was collected from about 75 $\mathrm{cm}$ below ground surface, while the other (FCN 2262) was collected from $1.3 \mathrm{~m}$ deep. The radiocarbon dates for these samples indicate that the lower sample came from a stratum dated to the middle of the second millennium B.C., while the later sample dated from the period of overlap between the Sanxingdui and Shi'erqiao / Jinsha cultural periods (Table 2). Although one must be very cautious when using only two radiocarbon dates recovered from exposed strata, these dates accord well with the excavation results from the site discussed below.

\section{GEOPHYSICAL SURVEY}

A range of geophysical techniques are available for archaeological prospection, including electrical methods (e.g., earth resistance), magnetic methods (e.g., magnetometry), and electromagnetic or EM methods (such as ground-penetrating radar or GPR). Based on the known ground conditions and the nature of the expected archaeological features, it was decided that magnetometry would be the most appropriate method for work in the Chengdu Plain. Earth resistance survey may be less effective due to the expectation that some archaeological remains would be below the detection limits of these techniques, but also because of the high water content of the soils resulting from irrigation. Measuring soil resistance provides a measurement of the moisture content and porosity of buried materials. Saturated ground reduces the moisture contrast between archaeological features and natural sediments. EM techniques, including GPR, are particularly sensitive to the conductivity, hence water content, of the ground and therefore have the same limitations as earth resistance. Furthermore, the dense network of rice paddy walls that divide up the landscape in this region would make a technique such as GPR extremely difficult.

In contrast, magnetometers have several advantages that make them attractive for use in this region. Magnetometry is the most rapid prospection method, can positively locate a wide range of anthropogenic features, and is well established in archaeological prospection (Aspinall et al. 2008; Clark 1990; Gaffney and Gater 2003; Scollar et al. 1990). This technique relies on the magnetic contrast between archaeological features and surrounding natural sediments. It is therefore highly dependent on the geological and pedological environment at a site. When successful, it is possible to detect the slightly more magnetic fills of buried pits and ditches and features such as hearths where the soils and clays have been burnt, thereby enhancing their magnetization. The magnetometer used for this project, the Bartington Grad601-2 dual 


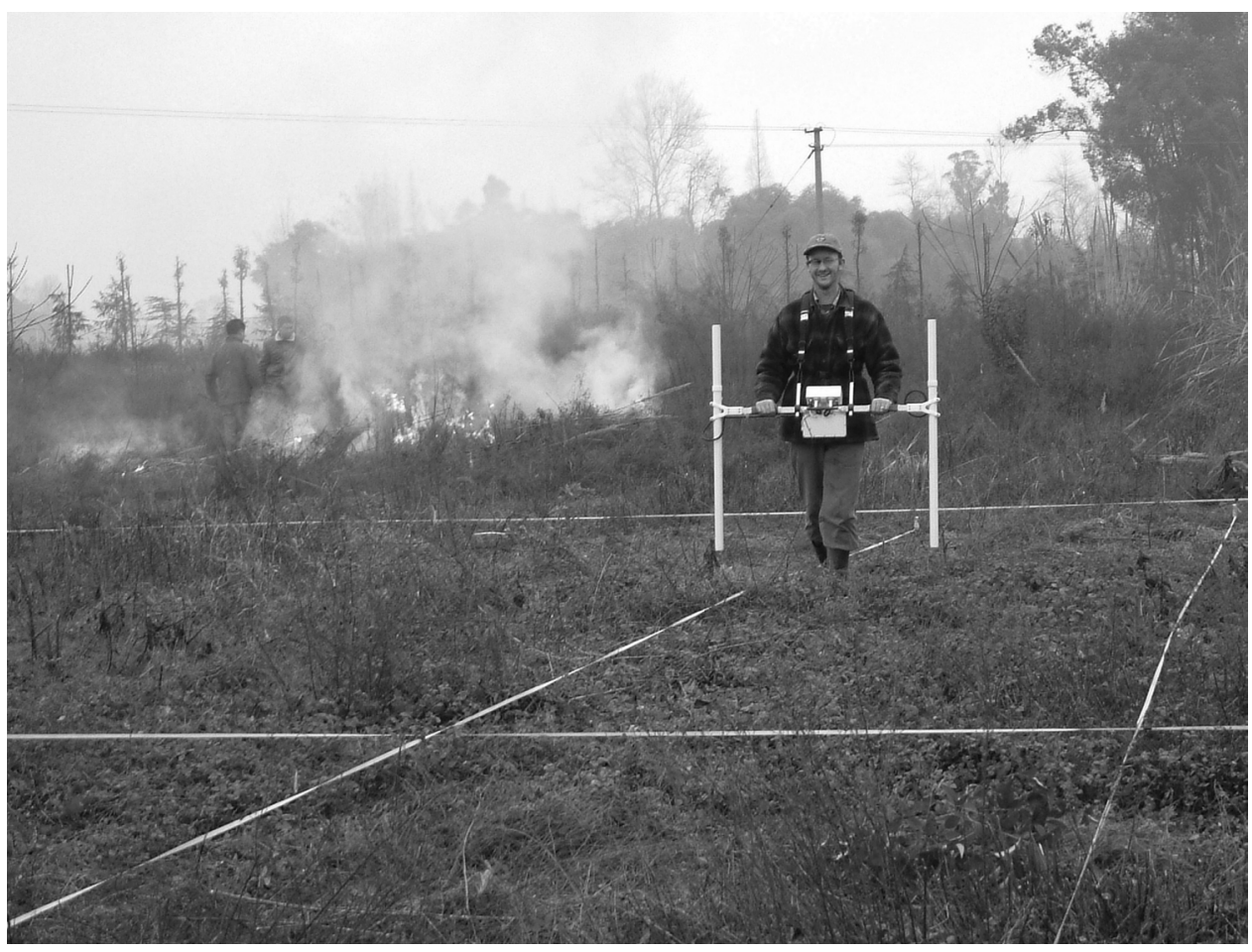

Fig. 5. Magnetometry survey at Songjiaheba.

gradiometer, can detect features up to $3 \mathrm{~m}$ deep, although this is dependent on the size of the feature and the degree of magnetic contrast with the surrounding material.

Magnetometer survey involves carrying an instrument (usually handheld) along transects within a gridded survey area (Fig. 5). Since vegetation and ground conditions affect the ease of data collection, in the Chengdu Plain magnetometer surveys are restricted to those times of year when rice paddies are drained, but before or after they have a dense vegetable crop. In the case of these investigations at Songjiaheba, the paddies within the survey area had been abandoned and were either stripped of topsoil or completely excavated to access the sand and gravel. The magnetometer survey discussed here was undertaken within $20 \mathrm{~m}$ squares at a resolution of $0.5 \mathrm{~m} \times 0.125 \mathrm{~m}$, making it possible to identify the majority of wall, ditch, hearth, and large pit features.

Following the geophysical survey at Songjiaheba, a selection of soil and sediment samples were collected in order to allow their magnetic susceptibility (MS) to be determined in the laboratory. The MS value of a material is dependent on how readily it becomes magnetized when placed in a magnetic field. Therefore, a contrast between natural and anthropogenic deposits can be indicative of the likely success of magnetometer surveys (Table 3). A sample of anthropogenic material taken from the exposed section has a susceptibility of $23.5 \times 10^{-8} \mathrm{~m}^{3} \mathrm{~kg}^{-1}$, compared to a sample of adjacent "natural" soil $\left(5.8 \times 10^{-8} \mathrm{~m}^{3} \mathrm{~kg}^{-1}\right)$. These limited MS measurements indicate that a sufficient magnetic contrast exists between anthropogenic and natural deposits for archaeological features to be detectable with this technique. 
Table 3. Calibrated Magnetic Susceptibility Measurements on Soil Samples Collected at Songjiaheba from Both Anthropogenic and Natural Deposits

\begin{tabular}{|l|c|}
\hline SAMPLE & $\begin{array}{c}\text { MAGNETIC SUSCEPTIBILITY } \\
\left(\times \mathrm{IO}^{-8} \mathrm{~m}^{3} \mathrm{~kg}^{-1}\right)\end{array}$ \\
\hline 1-Topsoil & 14.1 \\
\hline 2-Anthropogenic deposit (c. 1 m below original ground surface) & 23.5 \\
\hline 3-Soil adjacent to 2 (no anthropogenic inclusions) & 5.8 \\
\hline 4-Fragment of Han brick & 193.5 \\
\hline Sand & 24.6 \\
\hline Rock 1 & 1458.9 \\
\hline Rock 2 & 2.7 \\
\hline Rock 3 & 155.9 \\
\hline Rock 4 & 4.1 \\
\hline Rock 5 & 393.2 \\
\hline Rock 6 & 2.1 \\
\hline
\end{tabular}

The magnetometer results from Songjiaheba, shown in Plate 2 (left), reveal a complicated picture of anomalies. These are evident across the entire magnetometer survey, including the northwest area of the site where the soil has been completely stripped down to the underlying sands and gravels. While some of these anomalies are probably due to topographic variations resulting from the quarrying of sand and gravel that left the surface uneven, the results indicate that the natural deposits are magnetically heterogeneous and produce clear responses. This is backed up by a considerable range in the MS values of a number of rocks collected from gravel in this area (Table 3). This range reflects the variety of rock types that make up the gravel. While individual stones with high MS will produce intense magnetic anomalies in their vicinity, at a distance (i.e., when buried under a meter of soil) individual rocks become virtually undetectable. However, larger natural features, such as sand lenses within the gravel, will produce measurable anomalies at the ground surface if an MS contrast exists between the sand and the surrounding gravel.

Despite the magnetic noise, it is possible to identify archaeological responses within the gravel. The more intense anomalies (in excess of $\pm 12 \mathrm{nT}$ ) at [1] in Plate 2 (right) coincide with concentrations of brick, associated with Han tombs that had been sunk into the gravel. However, the bricks now lie exposed and are no longer in situ, and no other components of the tomb features remain. The attribution to the Han period is based on the brick composition, although no clear brick decoration was observed. A similar anomaly is seen at [2], which may also be due to a buried brick (possibly Han period) tomb.

In contrast to the quarried section of the survey area, the southeastern region is characterized by much subtler magnetic anomalies, generally less than $\pm 2 \mathrm{nT}$ in strength. These are more difficult to interpret, as a natural origin cannot be ruled out. 
As discussed above, it is possible that variations within the sand and gravel deposits could produce such detectable anomalies. Without further investigation (i.e., excavation), it is not possible to state their origin with any certainty. However, there is evidence to suggest that they may have archaeological sources.

In the southwestern part of the survey area there is a clear boundary between the subtle anomalies and a magnetically quiet area at [3]. It is possible that this represents a natural change in magnetic properties, (e.g., marking the edge of a palaeochannel); alternatively it might indicate the extent of buried archaeological features. It is interesting to note that the point where this boundary meets the edge of the quarry coincides with the location where anthropogenic deposits were visible in section. We consequently interpret this line as being the southwestern edge of the site area as reconstructed on Plate 1.

The lack of magnetic anomalies in area [3] also indicates that the c. $1.5 \mathrm{~m}$ overburden of soil/subsoil is sufficient to reduce the effect of natural responses to a level where they are essentially invisible. Unless there is a dramatic variation in the height of the gravel deposits, it is unlikely that the subtle anomalies found within the site area are geological in origin.

Numerous weakly positive responses have been identified (Plate 2 right). The stronger of these may be due to discrete areas of magnetic enhancement associated with burning. They could therefore indicate the locations of hearths or pits containing burnt material (e.g., anomalies [4] to [12] in Plate 3 right). The larger and weaker anomalies ([13] to [17] in Plate 3 right) are around $3 \mathrm{~m}$ in diameter and are consistent with the type of response seen over occupation areas, where the interiors of houses have a buildup of magnetically enhanced material. Extensive geophysical research in other parts of the world shows that this occurs in house features. Such an enhancement is suggested by the MS measurements discussed above. The precise nature of archaeological features that would produce such anomalies is unclear without excavation.

\section{EXCAVATION}

Salvage excavations to examine the nature of some of the geophysical anomalies were conducted at Songjiaheba in April 2007 due to the threat posed by continued quarrying of the sand. Excavation concentrated on the flat area where approximately $60 \mathrm{~cm}$ of topsoil had been removed and where the geophysical results suggested the presence of archaeological features. One $10 \times 10 \mathrm{~m}$ unit (07CPST1) and three trenches (07CPST2-4) were opened at the site (Plate 3). As a one-meter baulk was left around T1, a $9 \times 9 \mathrm{~m}$ section of this unit was excavated. The other excavations comprised one $9 \times 2.5 \mathrm{~m}$ trench $(\mathrm{T} 2)$ and two $6 \times 1.5$ meter trenches $(\mathrm{T} 3-4)$. The excavations exposed 10 pits of various sizes, two burials, and one partial house foundation. An additional two $1 \times 1 \mathrm{~m}$ units were excavated in July 2009 with the aim of examining the two round negative anomalies in the hope of extracting archaeobotanical material from the site (see below).

Excavations exposed five stratigraphic levels in this region (Fig. 6). The uppermost level, a mixed topsoil deposit, was $15-20 \mathrm{~cm}$ thick. Level 2 contained small numbers of porcelain and roof-tile fragments dating to the Ming (A.D. 1368-1644) and Qing (A.D. 1644-1911) dynasties, and level 3 contained Tang/Song (c. A.D. 600-1300) ceramics. Level 3 was cut by a Ming/Qing period pit (K2). Levels 4 and 5 contained most of the archaeological material. Pits H1-3 and burials M1-2 were found beneath 


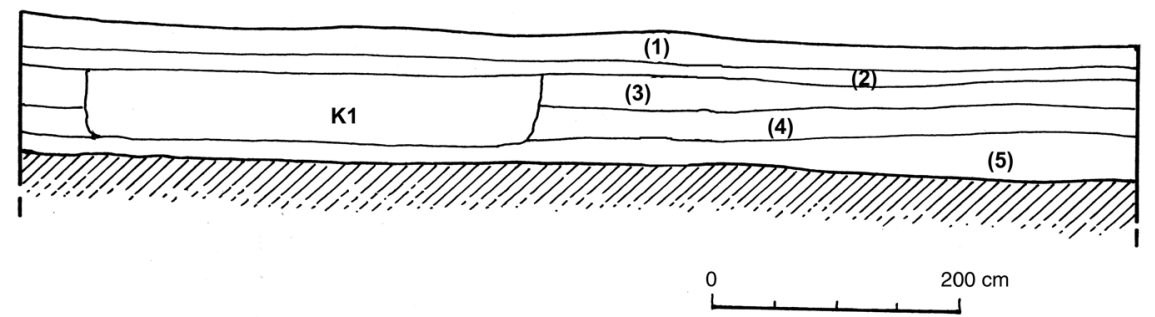

Fig. 6. East profile of Unit T2.

level 4 cutting into level 5 . The remainder of the features at the site, including Pits H3-10 and the partial house foundation (F1), were discovered beneath level 5 (see Plate 3).

The first small $1 \times 1 \mathrm{~m}$ excavation unit, TU1, was placed at the location of magnetic anomaly [8] (see Plate 3). This unit was excavated to sterile soil at $60 \mathrm{~cm}$. Three stratigraphic layers were visible in this unit. Directly underneath the topsoil, an artifact-and-ash-rich layer was unearthed. Although the boundaries of this feature were not found within this $1 \times 1 \mathrm{~m}$ unit, the large quantities of ash, pottery, and grinding stone contained in this matrix are consistent with the fill of a trash pit. A large soil sample $(53 \mathrm{~L})$ was taken from this layer.

TU2, a second small unit placed over anomaly [12], had more complex stratigraphy and, like other areas of the site, contained five stratigraphic layers. Underneath topsoil, the second stratigraphic layer contained "Shang / Zhou" period (c. 1500-300 B.C.) pottery and some ashy inclusions. ${ }^{4}$ An $11 \mathrm{~L}$ soil sample was taken from this layer. A thin stratum (Layer 3) containing no pottery or ashy inclusions was not sampled. Layer 4 contained a few ashy inclusions and an additional 13L soil sample was collected. Situated underneath this layer and cutting into what appeared to be sterile soil were the clear boundaries of a pit. An additional large sample of $31 \mathrm{~L}$ was taken from this feature.

The features uncovered in these six excavation units are consistent with those expected at a small settlement. The pits were all relatively shallow, between 30 and $60 \mathrm{~cm}$ in depth. They varied widely in shape, from circular to rectangular, and contained fragments of broken pottery and stone. Several artifacts were found near the partial house structure, a rectangular building constructed with wooden posts set into a shallow wall trench. The structure was approximately $4.3 \mathrm{~m}$ along the one preserved side, but had no distinguishable features other than a wall trench and a single posthole (Fig. 7).

Ceramics found in house feature F1 and in contemporary pits that are covered by level 5 suggest that this stratum was similar in date with level 6 at the Meiyuan Locus of the Jinsha site (Chengdu 2004) and levels 12-13 at the site of Shi'erqiao (Sichuan et al. 1987). As pointed out by Xu (2003), these strata are contemporary with the latest Bronze Age levels at Sanxingdui, a period that somewhat post-dates our earlier radiocarbon date from the augering mentioned above. Of course, the radiocarbon sample does not come from an excavation context and merely provides a starting point for discussing chronological questions at the site. The features below level 5 may date to somewhere around 1200-1150 B.C.

The Songjiaheba burials were more or less contemporaneous with each other, although burial M1 cut into burial M2 and was therefore slightly later (Fig. 8). They 


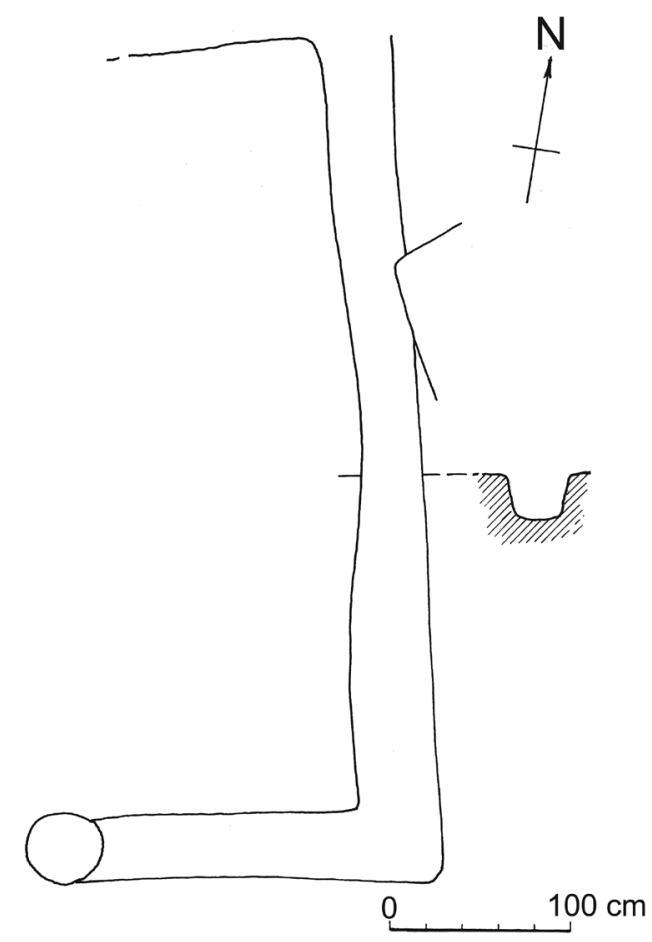

Fig. 7. Plan view of house foundation F1.

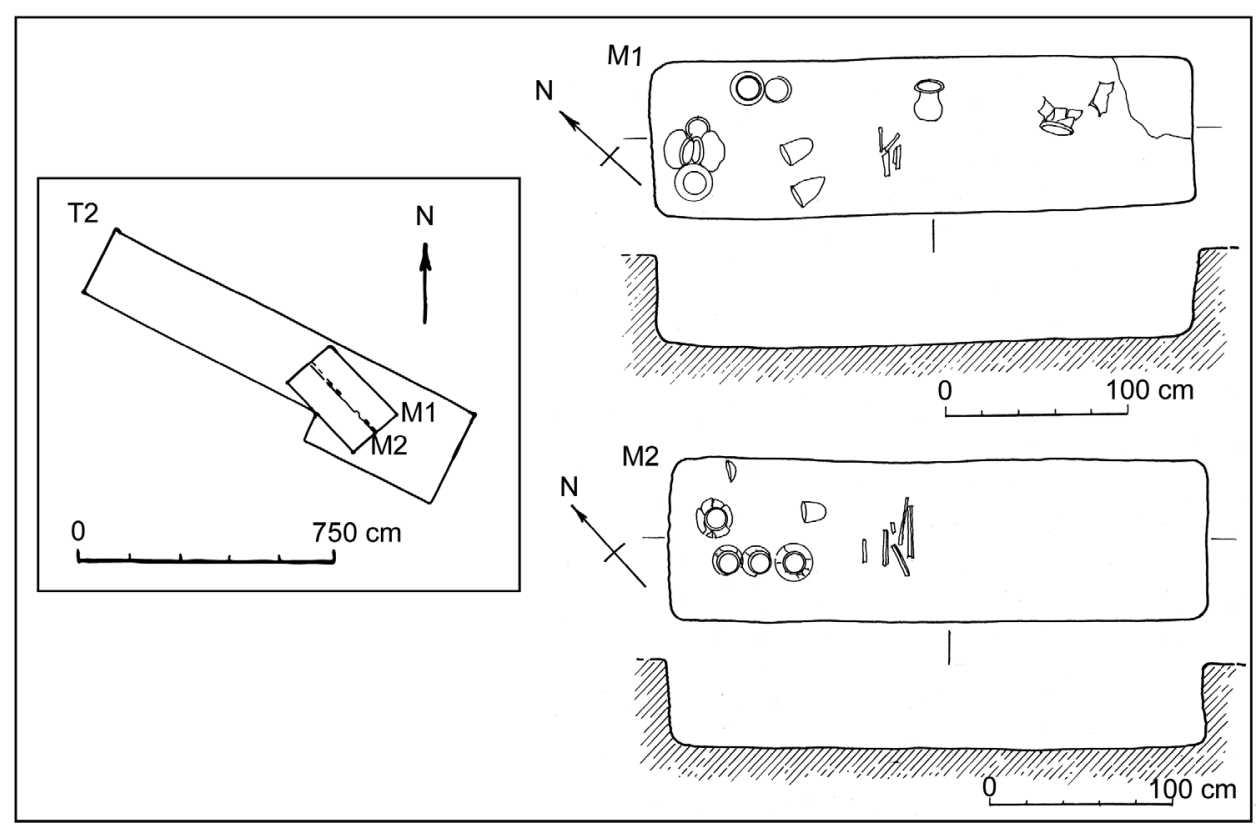

Fig. 8. Burial plans found in excavation of T2. 
post-date the house foundation and level 5. M1 was $2.95 \times 0.87 \mathrm{~m}$ and $0.50 \mathrm{~m}$ deep, oriented at about $315^{\circ}$. M2 was almost the same size $(2.95 \times 0.90 \times 0.50 \mathrm{~m})$ and orientation. Human remains in both graves were poorly preserved, although teeth fragments remained in the northwest portion of both graves. The occlusial wear on the teeth discovered in M1 are consistent with those expected from an adult, perhaps near 30 years in age. In M2, the individual should be around 9 years old based on the recent eruption of the lower canines.

Both burials contained burial goods including ceramic vessels and stone "sticks" or rods placed on the midsection of the deceased that were similar to objects found at other sites such as Shuiguanyin in Xinfan County, not too distant from the Songjiaheba site (Sichuan 1959). The function of these stone sticks is unclear and more work is necessary to clarify how widespread this burial practice was in the region. The sticks were quite fragmentary as was apparently also true of those found at Shuiguanyin. M1 at Songjiaheba also contained a total of 10 ceramic vessels (Fig. 9A): four roundedbottom jars (M1:4, 8), four shouldered jars with restricted mouths (M1:5), and two pointed-bottom cups (M1:2). M2 contained four shouldered jars (M2:2,6), one pointed-bottom cup (M2:5), and a pointed-bottom saucer (M2:1) in addition to the stone sticks (Fig. 9B). These objects suggest that the burials were relatively close to one another in date. They may have been members of a single family, with a younger individual buried earlier than an older one. The stone rods in both burials suggest a chronology contemporaneous with Shuiguanyin, the pointed-bottom saucer in M2 has parallels in level 12 at Shi'erqiao, and the pointed-bottom cup from the same burial is similar to ceramics found in Shi'erqiao level 11. Materials from level 4, su-

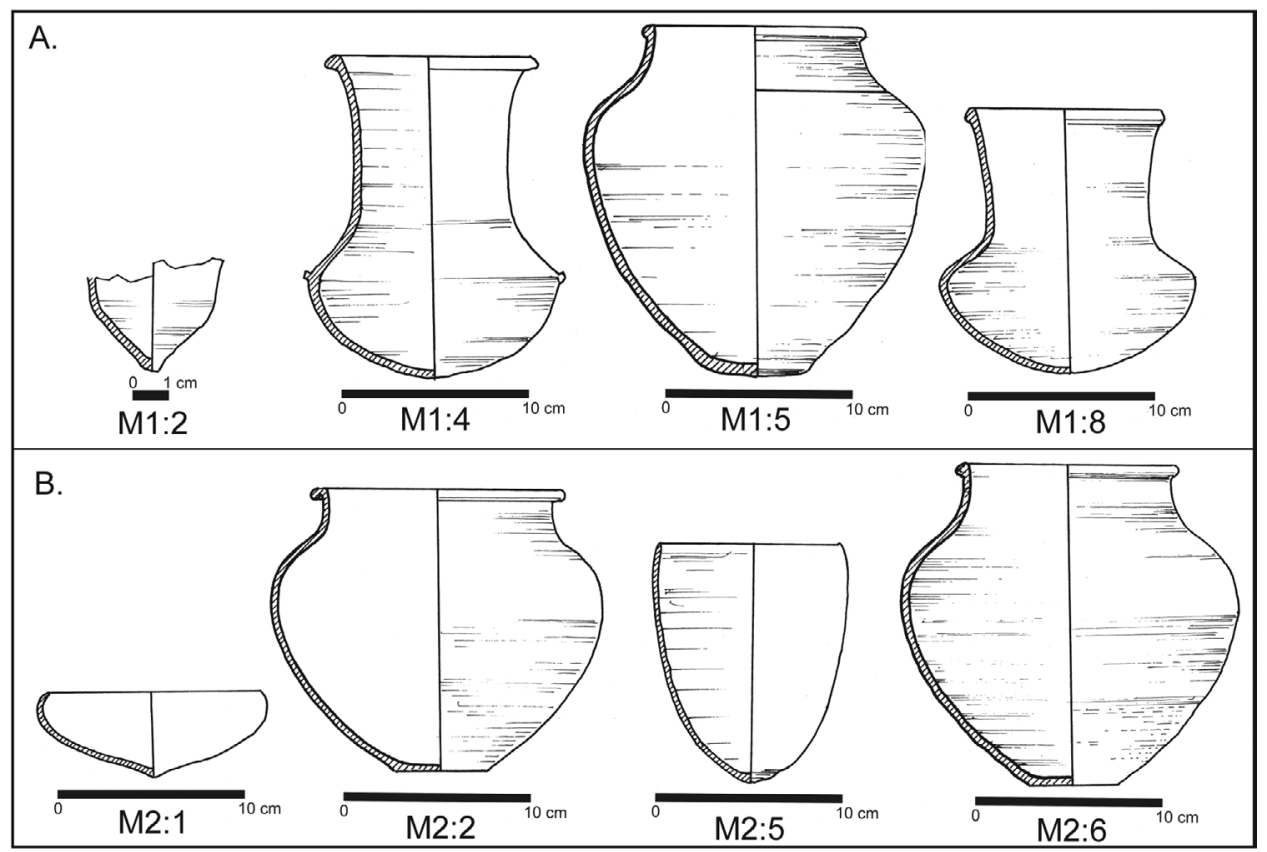

Fig. 9. Ceramics from M1 and M2. 
perimposed on top of the graves, are similar to objects from levels 11-10 from the site of Shi'erqiao, perhaps contemporary with the early to middle parts of the Western Zhou (c. 1150-771 B.C.; see Jiang 1998). All of these comparisons, coupled with the latter of the radiocarbon dates listed in Table 2, suggest that the graves date to sometime around 1100 B.C.

\section{COMPARISON OF EXCAVATION AND GEOPHYSICS RESULTS}

These excavation results have allowed the magnetometer data from Songjiaheba to be assessed. It is clear that features containing burnt deposits and high concentrations of ceramic material produce detectable positive magnetic anomalies, the shape of which can be related to the source feature. However, perhaps in part due to the underlying magnetic responses to geological variations, other more subtle features have not been detected. The excavated structure, for example, does not appear to have been identified by this magnetometer survey.

Pits filled with wood ash, despite their association with burning, do not usually produce a positive magnetic anomaly because of the absence of iron minerals in charcoal. Conversely, high quantities of such ash will produce a negative response because it contrasts negatively with natural soils and sediments. This has been shown to be the case at Songjiaheba as one negative anomaly was revealed to be associated with a rich wood-ash deposit. Unsurprisingly, since they often do not exhibit a sufficient magnetic contrast and are therefore difficult to identify in many environments, the graves did not produce any magnetic responses that would have aided in their location.

While somewhat problematic for the identification of subtle anomalies of archaeological origin, the ability of the magnetometer to respond to geological features has the benefit of providing information regarding buried geomorphological features. Results from other sites in the region (e.g., Horsley 2010) suggest that the pattern of magnetic responses in the northern portion of the survey indicate a palaeochannel that appears to divide the site in two. It is not possible to determine the age of this former river channel from the geophysical data alone. It is therefore unclear whether it was contemporaneous with the settlement or it represents a later event that washed away this area of the site.

\section{ARCHAEOBOTANICAL RESULTS}

Sediment samples were processed using simple bucket flotation similar to that described in Pearsall (2000). The light fraction was poured onto a $0.25 \mathrm{~mm}$ nylon mesh and the heavy fraction was processed using a $0.5 \mathrm{~mm}$ mesh sieve. To ensure efficiency and maximum data collection, different methods were applied to the sorting of fractions. The $2 \mathrm{~mm}$ fraction was sorted in its entirety. Seeds and plant parts were then identified while charcoal was reserved for subsequent analysis. The $1,0.5$, and $0.25 \mathrm{~mm}$ fractions were sorted in their entirety for both carbonized and modern seeds; however, charcoal and other parts were not pulled from these fractions. Identifiable plant parts, such as rice spikelet bases, were pulled from all fractions.

The Songjiaheba sediment samples yielded low densities of charred plant remains (see Table 4). Despite the fact that these remains were too sparse to aid in the 


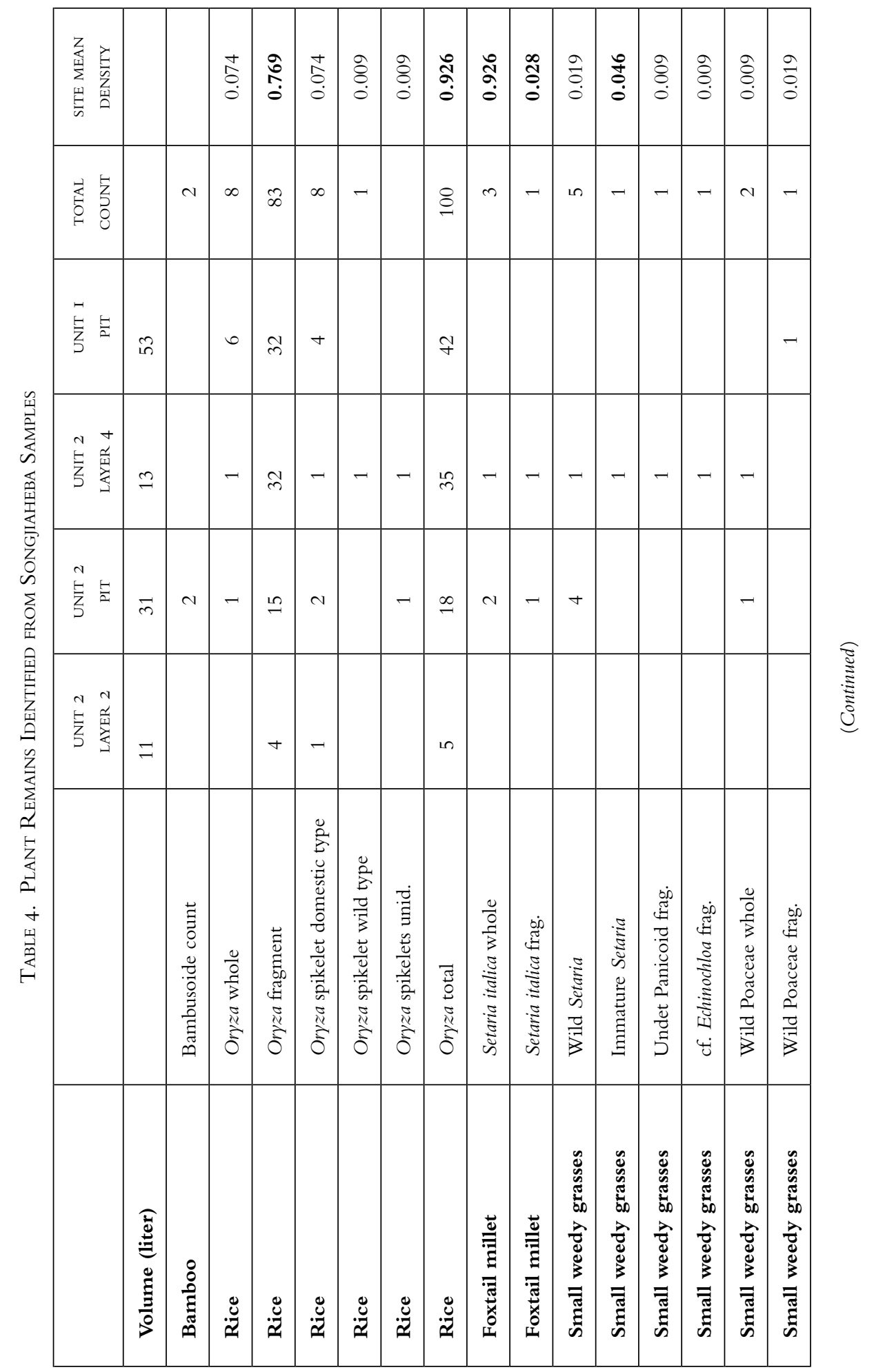




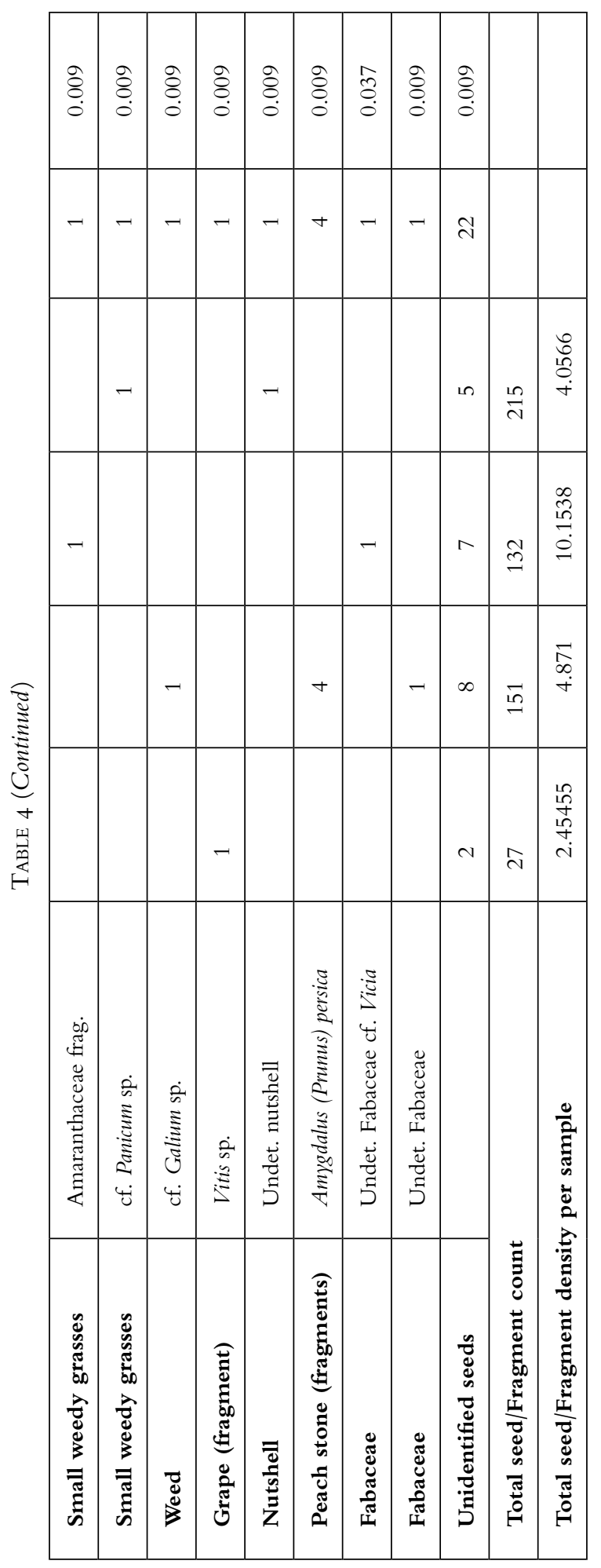


Table 5. Metric Information for Rice Grains

\begin{tabular}{|l|c|c|c|c|c|}
\hline SAMPLE NUMBER & $\begin{array}{c}\text { LENGTH } \\
(\mathrm{mm})\end{array}$ & $\begin{array}{c}\text { WIDTH } \\
(\mathrm{mm})\end{array}$ & $\begin{array}{c}\text { L/W } \\
\text { RATIO }\end{array}$ & $\begin{array}{c}\text { SCUTELLUM } \\
\text { LENGTH } \\
(\mathrm{mm})\end{array}$ & $\begin{array}{c}\text { SCUTELLUM/L } \\
\text { RATIO }\end{array}$ \\
\hline Unit 1 Pit rice grain (1) & 4.31 & 2.62 & 1.65 & & \\
\hline Unit 1 Pit rice grain (2) & 5.09 & 2.90 & 1.76 & & \\
\hline Unit 1 Pit rice grain (3) & 4.55 & 2.47 & 1.84 & & \\
\hline Unit 1 Pit rice grain (4) & 4.58 & 2.69 & 1.70 & & \\
\hline Unit 1 Pit rice grain (5) & 4.36 & 2.40 & 1.82 & & \\
\hline Unit 1 Pit rice grain (6) & 5.07 & 2.62 & 1.94 & & \\
\hline Unit 2 Layer 4 rice grain (1) & 5.48 & 2.44 & 2.25 & & \\
\hline Unit 2 Pit rice grain (1) & 4.28 & 2.88 & 1.49 & & 0.70 \\
\hline Unit 2 Pit Setaria italica & 1.24 & 1.26 & 0.98 & 0.87 & 0.71 \\
\hline Unit 2 Layer 4 Setaria italica & 1.26 & 1.28 & 0.98 & 0.90 & \\
\hline
\end{tabular}

interpretation of the site, they provide us with the first picture of the plants associated with subsistence at Sanxingdui-culture settlements. Only recently has any archaeobotanical work been done in Sichuan; none of it has yet been published for the Chengdu Plain. ${ }^{5}$ Extensive archaeobotanical analysis currently being undertaken by one of this article's authors (D'Alpoim Guedes) will soon provide a deeper understanding of agricultural activity and other plant exploitation in the region.

Subsistence at Songjiaheba appears to have focused on rice (Oryza sativa). Rice remains constitute the most numerous taxa, with a total of 90 specimens in this assemblage. Examination of the rice spikelet bases confirms the presence of domesticated rice (Fuller et al. 2009). Most of these specimens were very fragmentary with only 10 measurable rice grains (see Table 5). In addition to rice, small amounts of foxtail millet (Setaria italica), peach pit (Amygdalus [Prunus] persica), and wild grape (Vitis sp.) were recovered, as were seeds of members of the Poaceae family and Amaranthaceae family. While one cannot rule out their role as food, these are also common arable weeds. It is likely that these weeds grew alongside the rice or millet plants and were introduced to the site when the harvest was brought in.

\section{DISCUSSION AND CONCLUSION}

The site of Songjiaheba was a small settlement occupied in two separate phases during the second half of the second millennium B.C. In the earlier phase we found evidence of pits used to dispose of trash in the vicinity of residences. The second phase included two burials, most likely interred within a small settlement area. The site probably comprised a small hamlet, around 1.5 ha in size, near the banks of a stream. The general position and size of the site has been established using a combi- 
nation of augering and magnetometer survey. Numerous magnetic anomalies consistent with buried archaeological features have been identified at the site and, although ground-truthing remains somewhat limited, it appears that many of these may have archaeological origins. Excavations have shown that magnetometry is particularly useful for identifying pit features. These features have provided the first data available on plant exploitation during the Early Bronze Age in the Chengdu Plain.

These data contribute to the recent boom in survey archaeobotany in East Asia. The primary goal of extracting archaeobotanical data through survey has been to collect material from sites either not currently under excavation or to resample sites that were previously excavated. Much of this previous work has been carried out in regions where archaeological features are visible in agricultural terraces. As most sites in the Chengdu Plain are not visible on the surface, new methods of deciding where to target features are necessary. Magnetometry has been able to successfully locate such features.

Modern agricultural practices present limitations for geophysical survey in this environment. The extant paddy walls produce distinct anomalies in the survey data. While these are readily identifiable and can be ignored, they may obscure anomalies representing archaeological features buried below. Interestingly, no anomalies representing ancient paddy walls have been recognized, although it seems likely that the field layout shifted over time.

Of greater concern for actually undertaking the surveys and collecting data are the modern crops. The magnetometer is a handheld instrument that does not need to make contact with the ground; however, the operator is required to walk along parallel lines spaced either $2 \mathrm{~m}$ or $1 \mathrm{~m}$ apart. It is not possible to survey areas where valuable crops are closely spaced without damaging them. Not only does this slow the rate of survey, it results in gaps in areas where agricultural fields are present.

The area around the site at Songjiaheba was being excavated for sand and gravel, not cultivated, so this problem was mitigated. Elsewhere in the CPAS survey area, ground conditions were more disruptive. One solution to this would be to conduct geophysical surveys at a different time of year, for example after the paddies are drained and the ground firm enough to walk on, but before crops would be damaged. Alternatively, if the crops are rotated, it should be possible to build up a complete picture by undertaking surveys over consecutive years.

Despite these issues, the potential of geophysics as a method to complement traditional survey techniques is demonstrated by the work at Songjiaheba. Furthermore, the work here shows that systematic survey even in difficult environments has the potential to add significantly to our knowledge about ancient settlement patterns. Prior to the initiation of the CPAS survey, sites such as Songjiaheba were not known from across the Chengdu Plain. It has been difficult, therefore, to determine whether the highly dispersed settlement pattern that existed through the historical period was also typical for the Neolithic and Bronze Ages. Songjiaheba was a small settlement. It was perhaps not terribly consequential as a location of social or political influence during the period when it was occupied. However, the CPAS survey area and surrounding regions were quite possibly filled with small household groups and hamlets just like Songjiaheba, occupied by small families who maintained networks of relationships across the Chengdu Plain. Songjiaheba was one of hundreds of nodes in a 
web of human settlement that collectively made up the prehistoric settlement pattern of the region. We need to understand such small nodes if we hope to create a more nuanced interpretation of early occupation of this area.

\section{ACKNOWLEDGMENTS}

The project depended on support from members of the Chengdu City Institute of Archaeology and funding from all collaborating institutions as well as the Wenner-Gren Foundation and the Luce Foundation. Two anonymous reviewers commented on a previous version of this manuscript and helped us clarify the significance of the project, and two reviewers for Asian Perspectives helped strengthen and clarify the arguments we present.

\section{NOTES}

1. The term "jade" is commonly used in Chinese archaeology to refer to a variety of hardstone materials, regardless of actual mineralogical composition. Included are materials that contain some degree of nephrite or jadeite, also referred to as "hemijade" (Wen and Jing 1992), and others that are minerologically distinct "pseudo-jades" (Middleton and Freestone 1995).

2. See for example the following archaeological survey reports: Chifeng 2011; Gansu and Beijing 2011; Gansu et al. 2008; Zhong-Mei 2012; Zhongguo et al. 2011.

3. In addition to the survey reports cited previously, see: Cai et al. 1997; Chen et al. 2003; Chifeng Lianhe 2003; Chifeng Zhong-Mei 2003; Linduff et al. 2004; Liu and Chen 2001; Liu et al. 2002-2004; Shelach 1998; Underhill et al. 1998, 2002, 2008.

4. The Bronze Age in this area, which by Chinese archaeological convention is imprecisely referred to as the "Shang/Zhou" era, can be subdivided into several phases (outlined in Table 1). Not all ceramics collected by CPAS can be clearly associated with one of these phases, since Bronze Age ceramics are relatively distinct from earlier, Baodun-culture ceramics and later, Han period ceramics. Following the conventions used in the archaeology of this region, we use the "Shang/Zhou" designation when more precise chronology cannot be determined based on the characteristics of the ceramics.

5. Note the complete lack of references to Sichuan archaeobotanical results from lowland Sichuan in Zhang and Hung 2010. Numerous archaeobotany publications by Jade D’Alpoim Guedes, Jiang Ming and other completed after this article went to press are addressing this lacuna but cannot be cited here.

\section{REFERENCES CITED}

Aspinall, Arnold, Chris Gaffney, and Armin Schmidt

2008 Magnetometry for Archaeology. Lanham: AltaMira Press.

BAgLey, Robert W.

2001 Ancient Sichuan: Treasures from a Lost Civilization. Seattle, WA: Seattle Art Museum and Princeton University Press.

Cai Fengshu 蔡鳳書, Yu Haiguang 于海廣, Luan Fengshi 欒豐實, Fang Hui 方輝, Anne Underhill, Gary Feinman, Linda nicholas, and Gwen Bennett

1997 Shandong Rizhao Shi Liangcheng diqu de kaogu diaocha 山東日照市兩城地區的考古調查 (Archaeological survey in the Liangcheng region of Rizhao City, Shandong). Kaogu 考古 [Archaeology] 4:1-17.

Chen Xingcan 陳星橴, Liu Li 劉莉, Li Runquan, Henry T. Wright, and Arlene Miller Rosen

2003 Zhongguo wenming fudi de shehui fuzahua jincheng: Yiluohe diqu de juluoxingtai yanjiu 中國文明腹地的社會複雜化進程—伊洛河地區的聚落型態研究 (The progress to social complexity at the core of Chinese civilization: Research on the settlement pattern of the Yiluo River area). Kaogu Xuebao 考古學報 [Acta archaeologica sinica] 2:161218.

Chengdu [Chengdu Pingyuan Guoji Kaogu Diaochadui 成都平原國際考古調查隊]

2010 Chengdu pingyuan quyu kaogu diaocha (2005-2007) 成都平原區域考古調查 (2005-2007 archaeological survey in the Chengdu Plain). Nanfang minzu kaogu 南方民族考古 [Southern ethnoarchaeology] 6:255-278. 
Chengdu [Chengdu Shi Wenwu Kaogu Yanjiusuo 成都市文物考古研究所]

2002 Chengdu Shi Shangyejie chuanguan, dumuguan muzang fajue baogao 成都市商業街船棺、 獨木棺墓葬發掘報告 (Report on the excavations of the boat-coffin and wooden coffin burials at Shangyejie in Chengdu). Chengdu kaogu faxian 成都考古發現 [Archaeological discoveries in Chengdu] 2000:78-136.

2004 Chengdu Jinsha yizhi yi qu “Meiyuan” didian fajue yi qi jianbao 成都金沙遺址一區 “梅苑”地點發掘一期簡報 (Preliminary report on the phase I excavation at the “Meiyuan” locus of the Jinsha site in Chengdu). Wenwu 文物 [Cultural relics] 2004(4):4-65.

Chengdu, Sichuan, and Waseda [Chengdu Shi Wenwu Kaogu Yanjiusuo 成都市文物考古研究 所, SichuAn Daxue Lishixi KaOgU JiaOYANSHi 四川大學歷史系考古教研室, AND WASEDA DAIGAKU CHŌKŌ RYŪIKI BUNKA KenKyŪJO 早稻田大學長江流域文化研究所]

2000 Baodun yizhi: Xinjin Baodun yizhi fajue he yanjiu 寶墩遺址：新津寶墩遺址發掘和研究 [The Baodun site: Excavation and research on the Xinjin Baodun site]. Chengdu 成都: Chengdu Shi Wenwu Kaogu Yanjiusuo 成都市文物考古研究所.

Chengdu and Beijing [Chengdu Shi Wenwu Kaogu Yanjiusuo 成都市文物考古研究所 And BeiJiNG Daxue KaOgu Wenboyuan 北京大學考古文博院]

2002 Jinsha taozhen-Chengdu Shi Jinshacun yizhi chutu wenwu 金沙淘珍——成都市金沙村遺址 出土文物 [Panning for treasure at Jinsha-Artifacts excavated from the Jinsha village site in Chengdu City]. Beijing 北京: Wenwu chubanshe 文物出版社.

Chengdu Institute [Chengdu Institute of Cultural Heritage and Archaeology]

2006 The Jinsha Site: A 21st Century Discovery of Chinese Archaeology. Beijing 北京: China International Press 五洲傳播出版社.

Chengdu Wenwu [Chengdu Wenwu Kaogu Yanjiusuo 成都文物考古研究所]

2006 Jinsha yuqi 金沙玉器 [Jade of the Jinsha Site]. Beijing 北京: Kexue chubanshe 科學出版社.

Chifeng [Chifeng International Collaborative Research Project]

2011 Settlement Patterns in the Chifeng Region. Pittsburgh: Center for Comparative Archaeology, University of Pittsburgh.

Chifeng Lianhe [Chifeng Lianhe Kaogu Diaochadui 赤峰聯合考古調查隊 (Chifeng Collaborative Survey Archaeology Team)]

2003 Neimenggu Chifeng diqu 1999 nian quyuxing kaogu diaocha baogao 內蒙古赤峰地區1999 年區域性考古調查報告 (Report on the 1999 regional archaeological survey in the Chifeng region of Inner Mongolia). Kaogu 考古 [Archaeology] 5:408-418.

Chifeng Zhong-Mei [Chifeng Zhong-Mei Lianhe KaOgu Yanjiu Xiangmu 赤峰中美聯合考古研究 項目 (Chifeng China-U.S. Collaborative Archaeological Research Project)]

2003 Regional Archaeology in Eastern Inner Mongolia: A Methodological Exploration. Beijing 北京: Kexue chubanshe 科學出版社.

Clark, Anthony J.

1990 Seeing Beneath the Soil: Prospecting Methods in Archaeology. London: B. T. Batsford, Ltd.

Demattè, Paola

1999 Longshan era urbanism: The role of cities in predynastic China. Asian Perspectives 38(2): 131153.

FLAD, ROWAN K.

2012 Bronze, jade, gold and ivory: Valuable objects in ancient Sichuan, in The Construction of Value in the Ancient World: 258-287, ed. J. K. Papadoupoulos and G. Urton. Los Angeles: Cotsen Institute of Archaeology.

Flad, Rowan, and Pochan Chen

2013 Ancient Central China: An Archaeological Study of Centers and Peripheries along the Yangzi River. Cambridge: Cambridge University Press.

Fuller, Dorian Q., Ling Qin, Yunfei Zheng, Zhijun Zhao, Xugao Chen, Leo Aoi Hosoya, and GUO-PING SUN

2009 The domestication process and domestication rate in rice. Science 323:1607-1609.

Gaffney, Chris F., And John A. Gater

2003 Revealing the Buried Past: Geophysics for Archaeologists. Stroud: Tempus Publishing, Ltd.

Gansu, Zhongguo, Beijing, ShaAnxi, and Xibei [Gansu Wenwu Kaogu Yanjiusuo 甘肅省文物] 考古研究所, Zhongguo Guojia Bowuguan 中國國家博物館, Beijing Daxue Kaogu Wenbo 
Xueyuan 北京大學考古文博學院, ShaAnXi Sheng KaOgu Yanjiuyuan 陝西省考古研究院, AND Xibei Daxue Wenbo XueYuan 西北大學文博學院]

2008 Xi Han shui shangyou kaogu diaocha baogao 西漢水上游考古調查報告 [Archaeological investigative report of the upper reaches of the Xinhuashui River]. Beijing 北京: Wenwu chubanshe 文物 出版社.

Gansu and Beijing [Gansu Sheng Wenwu Kaogu Yanjiusuo 甘肅省文物考古研究所, and Beijing Daxue Kaogu Wenbo Xueyuan 北京大學文博考古學院]

2011 Hexi zoulang shiqian kaogu diaocha baogao 河西走廊史前考古調查報告 [Report on the archaeological survey of prehistoric sites in the Hexi corridor]. Beijing 北京: Wenwu chubanshe 文物出版 社.

Horsley, Timothy J.

2010 Diqiu wuli jishu zai Zhongguo Sichuan Chengdu Pingyuan kaogu gongzuo zhong de yingyong 2006 nian 12 yue-2007 nian 1 yue 地球物理技術在中國四川成都平原考古工作 中的應用 2006年12月-2007年1月(The utility of geophysical techniques in China based on archaeological research in the Chengdu Plain, Sichuan-Dec. 2006-Jan. 2007). Nanfang minzu kaogu 南方民族考古 [Southern ethnoarchaeology] 6:279-294.

JIANG ZHANGHUA 江章華

1998 Chengdu Shi'erqiao yizhi de wenhua xingzhi yu fenqi yanjiu 成都十二橋遺址的文化性質 及分期研究 (Research on the cultural character and chronology of the Shi'erqiao site in Chengdu), in Sichuan daxue kaogu zhuanye chuangjian sanshiwu zhounian jinian wenji 四川大學 考古專業創建三十五周年紀念文集 [Volume commemorating thirty-five years of Archaeology at Sichuan University]: 146-164, ed. Sichuan Daxue Kaogu Zhuanye 四川大學考古專業. Chengdu 成都: Sichuan Daxue chubanshe 四川大學出版社.

Linduff, Katheryn M., Robert D. Drennan, and Gideon Shelach

2004 Early complex societies in NE China: The Chifeng International Collaborative Archaeological Research Project. Journal of Field Archaeology 29(1/2): 45-73.

LIU LI

1996 Settlement patterns, chiefdom variability, and the development of early states in North China. Journal of Anthropological Archaeology 15(3): 237-288.

LiU Li AND Chen Xingcan

2001 Settlement archaeology and the study of social complexity in China. The Review of Archaeology 22(2): 4-22.

Liu Li, Chen Xingcan, Yun Kuen Lee, Henry T. Wright, and Arlene rosen

2002- Settlement patterns and development of social complexity in the Yiluo region, North China. 2004 Journal of Field Archaeology 20(1/2) :75-100.

Middleton, Andrew, and Ian Freestone

1995 The mineralogy and occurence of jade, in Chinese Jade: From the Neolithic to the Qing: 413-423, ed. Jessica Rawson. London: British Museum Press.

Pearsall, Deborah

2000 Paleoethnobotany: A Handbook of Procedures. San Diego: Academic Press.

REN SHINAN 任式楠

1998 Zhongguo shiqian chengzhi kaocha 中國史前城址考察 [Survey of prehistoric walled sites in China] (Investigations of the town wall remains of Chinese prehistory). Kaogu 考古 [Archaeol$o g y] 1: 1-16$.

Scollar, Irwin, Alain Tabbagh, Albert Hesse, and Irmela Herzog

1990 Archaeological Prospecting and Remote Sensing: Topics in Remote Sensing. Cambridge: Cambridge University Press.

SHELACH, GideON

1998 A settlement pattern study in Northeast China: Results and potential contributions of Western theory and methods to Chinese archaeology. Antiquity 72(275):114-127.

Sichuan [Sichuan SHeng Bowuguan 四川省博物館]

1959 Sichuan Xinfan Xian Shuiguanyin yizhi shijue jianbao 四川新凡縣水觀音遺址試掘簡報 [Preliminary report on the excavation of the Shuiguanyin site in Xinfan County, Sichuan] (Excavation report of the Shuiguanyin site in Xinfan, Sichuan). Kaogu 考古 [Archaeology] 8:404-410. 
Sichuan [Sichuan Sheng Wenwu Kaogu Yanjisuo 四川省文物考古研究所]

1999 Sanxingdui jisikeng 三星堆祭祀坑 [The ritual pits of Sanxingdui] [Excavation of the Sacrificial Pits at Sanxingdui]. Beijing 北京: Wenwu chubanshe 文物出版社.

Sichuan, Sichuan, and Chengdu [Sichuan Sheng Wenwu Guanli Weiyuanhui 四川省文物管理委 員會, Sichuan SHEng Wenwu KaOgu Yanjisuo 四川省文物考古研究所, AND ChengDu SHI BowUGUAN 成都市博物館]

1987 Chengdu Shi’erqiao Shangdai jianzhu yizhi di yi qi fajue jianbao 成都十二橋商代建築遺址 第一期發掘簡報 (Preliminary excavation report on the first period of the Shang period structure at Shierqiao, Chengdu). Wenwu 文物 [Cultural relics] 12:1-23, 37.

UNDERHILl, ANNE P.

1994 Variation in settlements during the Longshan Period of Northern China. Asian Perspectives 33: 197-228.

Underhill, Anne P., Gary M. Feinman, Linda M. Nicholas, Gwen Bennett, Cai Fengshu, Yu Haiguang, Luan Fengshi, and Fang Hui

1998 Systematic regional survey in southeastern Shandong Province, China. Journal of Field Archaeology 25 : 453-474.

2002 Regional survey and the development of complex societies in southeastern Shandong, China. Antiquity 76:745-755.

Underhill, Anne P., Gary M. Feinman, Linda M. Nicholas, Hui Fang, Fengshi Luan, Haiguang Yu, and Fengshu Cai

2008 Changes in regional settlement patterns and the development of complex societies in southeastern Shandong, China. Journal of Anthropological Archaeology 26:1-29.

WANG YI

2003 Prehistoric walled settlements in the Chengdu Plain. Journal of East Asian Archaeology 5(1-4) : 109-148.

WeN GUANG AND JiNG ZHICHUN

1992 Chinese Neolithic jade: A preliminary geoarchaeological study. Geoarchaeology 7(3):251275.

Xu Hong 許宏

2000 Xianqin chengshi kaoguxue yanjiu 先秦城市考古學研究 [Archaeological research on pre-Qin cities]. Beijing 北京: Yanshan 燕山.

$\mathrm{XU}, \mathrm{JAY}$

2003 Defining the Archaeological Cultures at the Sanxingdui Site. Journal of East Asian Archaeology 5(1-4): 149-190.

YAN WENMING

1999 Neolithic settlements in China: Latest finds and research. Journal of East Asian Archaeology $1(1-4): 131-148$.

YANG XIAONENG

2004 Urban revolution in Late Prehistoric China, in New Perspectives on China's Past: Chinese Archaeology in the Twentieth Century: 98-143, ed. Yang Xiaoneng. New Haven: Yale University Press.

Zhang Chi and Hung HsiaO-Chun

2010 The emergence of agriculture in southern China. Antiquity 84(323):11-25.

Zhong-Mei [Zhong-Mei Rizhao DiQu Lianhe Kaogudui 中美日照地區聯合考古隊]

2012 Lu dongnan yanhai diqu xitong kaogu diaocha baogao 魯東南治海地區系統考古調查報告 $[R e-$ port on the systematic archaeological survey of the coastal region in southeastern Shandong]. Beijing 北京: Wenwu chubanshe 文物出版社.

Zhongguo, Shanxi, and Yuncheng [Zhongguo Guojia Bowuguan Tianye Kaogu Yanjiusuo 中國] 國家博物館田野考古研究, SHANXI SHENG KAOGU YANJIUSUO 山西省考古研究所 AND YUNCHENG SHI WeNWU BAOHU YANJIUSUO 運城市文物包古研究所]

2011 Juluo kaogu diaocha yu yanjiu - Yuncheng pendi dongbu 聚落考古調查與研究一一運成盆地東 部 [Survey and research of settlement archaeology in the Eastern Yuncheng Basin]. Beijing 北京: Wenwu chubanshe 文物出版社.

Zhu Zhangyi, Zhang Qing, AND WANg Fang

2003 The Jinsha site: An introduction. Journal of East Asian Archaeology 5(1-4) : 247-276. 


\section{ABSTRACT}

Archaeological survey in the Chengdu Plain of Sichuan Province has revealed settlement patterns surrounding Late Neolithic walled sites, including large numbers of small settlements from the Neolithic, Bronze Age, and Han Dynasty eras. Here geophysical survey and excavation at one of these small-scale sites dating to the Middle Bronze Age are reported, showing for the first time the value of high-resolution geophysics for evaluating site size and integrity in the Chengdu region. Keywords: Chengdu Plain, Sichuan, Sanxingdui, Shi'erqiao, geophysics, magnetometry, archaeobotany, settlement patterns. 